\title{
Socio-Economic Feasibility Analysis for Sustainable Mass Rapid Transit Project in Western India
}

\author{
Anal Sheth and *Debasis Sarkar
}

\begin{abstract}
First submission: 26 March 2019; Accepted: 20 March 2020; Published: 15 December 2020
To cite this article: Anal Sheth and Debasis Sarkar (2020). Socio-economic feasibility analysis for sustainable mass rapid transit project in Western India. Journal of Construction in Developing Countries, 25(2): 129-151. https://doi.org/10.21315/ jcdc2020.25.2.5.
\end{abstract}

To link to this article: https://doi.org/10.21315/jcdc2020.25.2.5

\begin{abstract}
Sustainable public transport systems may be achieved by adopting electric bus locomotion. The problem being addressed by this research is the development and case application of a computation methodology of the social benefit cost ratio of an electric bus transport project in India and identification of whether it can significantly favour the situation of environment friendly transport. The underlying theory behind this approach is if the environmental and social dimensions of an infrastructure project are considered in addition to the financial dimensions for the purpose of project appraisal, a holistic evaluation can be achieved and such an evaluation can give an edge to the approval of environmentally friendly projects. The evaluation has been performed using the present worth analysis of various types of benefits and costs associated with the implementation of the electric bus rapid transit system in a city. The variables considered in the researched methodology are benefits which are revenue, savings in vehicle operating costs (VOC), environmental benefits, savings in travel time, reduction in accidents and non-consumption of fossil fuel, and costs which are infrastructure investment costs, cost of the bus fleet, maintenance cost, replacement costs, cost of system operation and maintenance and additional electric power generation. The outcome as indicated by the value of the social benefit-cost ratio (SBCR) illustrates that such projects can be positively justified from point of view of the benefits gained by the society as well as fruifful returns and value addition of infrastructure investment in the long run. The research contributes by validating that social benefit-cost analysis (SBCA) can be used for the evaluation of sustainable transport system appraisals in order to make their realisation more favourable.
\end{abstract}

Keywords: Social benefit-cost ratio, Electric buses, Life cycle cost, Public transport, Sustainable transport

\section{INTRODUCTION}

Electric vehicles as opposed to fossil fuel based vehicles have no tailpipe emissions and if the electricity is generated from renewable sources, the source emissions can also be reduced. There are considerable efforts being done in the present era to shift the fossil fuel vehicle scenario to electric vehicle scenario. In step with the global trend towards the adoption of electric vehicles of different segments, the government of India, as well as other sectors, have also expressed extensive interest in fast and large scale adoption of electric vehicles. The expression has come in various forms such as reported targets of electric vehicle shift, enabling policies, indigenous manufacturing and approval of electric buses and other research and 
development efforts by institutions (GGGI [Global Green Growth Institute] and CSTEP [Center for Study of Science, Technology and Policy], 2015; SIAM [Society of Indian Automobile Manufacturers], 2016; TERI [The Energy and Resources Institute] and YES Bank, 2018).

Sustainable mass transits can be achieved by using electric buses and can have economic, social and environmental benefits. However, for transportation systems project appraisals, the environmental and social aspects are often neglected, due to which justice is not done to values other than financial, ultimately rendering the projects non-feasible even though it may have intangible benefits (Florio and Sirtori, 2016). The social and environmental aspects of the transportation systems are often neglected because objective evaluation of these intangible aspects is a grey area and monetisation of these aspects is not standardised in India, as it is in other countries like the United Kingdom (Hickman and Dean, 2017).

The problem being addressed by this research is the development and case application of a computation methodology of the social benefit cost ratio of an electric bus transport project in India and identification of whether it can significantly favour the situation of environment friendly transport. This research attempts to perform a quantitative analysis of an electric bus transport system in an urban context considering all three aspects of sustainability, which are economic, social and environmental. The electric bus transport system is a bus rapid transport system (BRTS) which is a bus service that runs on dedicated corridor.

The analysis involves the identification of various types of benefits and costs associated with the electric bus transport system in the city, their respective quantification in equivalent monetary terms, accounted with respect to the time value over the life span of the transport system infrastructure (AJL [Ahmedabad Janmarg Limited], 2018). The evaluation of the electric bus transport system for the selected case city which is Ahmedabad, India as indicated by the social benefitcost ratio (SBCR) has been presented.

The SBCR is reflected with other comparative indicators for the case of the electric bus transport system (Ito and Managi, 2015; EMA [Electric Mobility Alliance], 2017). The case taken here is for the bus rapid transportation system in Ahmedabad (A-BRTS), a city located in Western India. A partial network of the A-BRTS of the scale of $185.1 \mathrm{~km}$ is being considered for electrification by the city authorities presently and therefore, this part of the network has been considered for this research as well (AJL, 2018). Given the transit computations, this will involve plying of 88 electric buses corresponding to 32,533 daily vehicle-km.

The objective of this research is to frame a methodology for social benefitcost analysis (SBCA) and evaluate the SBCR for the proposed electric bus transit for Ahmedabad.

This article has been organised as follows: first, literature pertaining to benefitcost analysis studies in the transportation sector has been reviewed and presented. Next, the methodology used in this particular study has been explained. The section after that demonstrates the application of this technique on the dataset of the bus rapid transit system in Ahmedabad. The results of the case study are later discussed and the last section draws upon conclusions from the analysis and presents the futuristic relevance of the study outcome. 


\section{LITERATURE REVIEW}

\section{Benefit-Cost Analysis}

Benefit-cost analysis has historically been applied to evaluate alternative transport projects and aid in decision making and policy formulations. History reveals that in the 1970s, Barrell and Hills (1972) have reflected on the thoroughness and comprehensiveness of benefit-cost studies of transport investment projects during the time in Britain. Their recommendations from the study included considerations of equity, use of discounted cash flow techniques and sensitivity analysis for cost benefit studies of the future. Two decades later, DeCorla-Souza et al. (1997) illustrated the concept of total cost analysis over traditional benefit-cost analysis for comparing transport projects. In their methodology, they aggregated all the monetisable cost components including "cost savings" which were referred to as "benefits" in traditional analysis techniques. Non-monetised benefits or impacts were traded off in comparison to the total cost of various alternatives for the purpose of selecting the most attractive solution. The total cost analysis technique apparently has some advantages over the traditional benefit-cost analysis as it offers more simplicity in understanding and freedom of judgement.

\section{Challenges of benefit-cost analysis techniques}

Many researchers have brought into discussion the challenges associated with benefit-cost analysis as a technique and the capacity of benefit-cost analysis frameworks in decision making. For example, Mouter, Annema and Van Wee (2015) identify the limitations of benefit-cost analysis in the context of Dutch appraisal practice for infrastructure projects. Some of these limitations include incomplete analysis, uncertainty and difficulties of effect estimations. Asplund and Eliasson (2016) also address the sensitive question of uncertainties in benefit-cost assessments and their influence on public infrastructure investment decisions. These uncertainties were primarily pertaining to the investment costs and fluctuating transport demand. They have performed real data simulations of national infrastructure plans in Sweden and Norway for evaluating the effect of these uncertainties on investment selection. However, they positively concluded that though it is best to reduce the uncertainties about investment cost and demand, investment decisions based on benefit-cost assessments are not that sensitive to these uncertainties. Florio and Sirtori (2016) also point out the methodological issues of benefit-cost analysis for capital intensive infrastructures. Their proposed model which involves comprehensive evaluation based on six different categories of economic benefits can be applied for ex-ante project assessment. These six categories of economic benefits include technological spillovers, human capital formation, knowledge outputs, cultural effects, services to third parties including consumers and public good. Hickman and Dean (2017) argue about the current transport appraisal process in the United Kingdom (UK) which uses benefit-cost analysis for its predominantly quantitative nature. According to them, the importance of qualitative impacts including social, human life, natural and built environment is overlooked by this strategy. They support their view by two case studies and propose a participatory multi-criteria approach for development. Martens and Floridea (2017) have observed the criticism of the benefit-cost analysis methodology of transport projects from equity perspectives 
of transport planners. In their study, they target travel time savings and accessibility gains and their effects on the benefit-cost analysis. They conclude that accessibility gains can address equity effects (needs of disadvantaged population groups) only partially and cannot replace travel time savings within the benefit-cost analysis framework.

\section{Effect of scale and integration on benefit-cost analysis}

Other researchers have realised that benefit-cost analysis technique can be applied to assess the economies of larger scale for infrastructure projects. For example, Viton (1993) studied the many public urban transit providers in the San Francisco Bay area in order to examine the effect of scale and organisational changes in the transit system on cost economy. The research supported the formation of larger multimodal transit systems in the area as well as the selection of the right direction of transit for maximising benefits. Also, the importance of the selection of candidates for reorganisation has been emphasised as a recommendation. Anas, Tamin and Wibowo (2016) acknowledge the microeconomic and macroeconomic analysis tools for the transportation sector and have attempted to make a contribution for broader (regional) economic benefits of new transportation investment in Indonesia. Sun and Cui (2018a) have also taken a broader approach for the evaluation of economic benefits of urban infrastructure and have come up with an integrated four-pronged approach that takes into account the effects of consumption-investment, government purchase effect and external demand. They conclude that such coordinated development level has the potential to improve the overall economy of urban infrastructure. In another study also by Sun and Cui (2018b), the coordinated development of economic, social and environmental benefits has been evaluated for the case of four Chinese municipalities that have large scale public transport infrastructure by creating coupling coordination degree model and regression techniques. Their results indicated that coordinated development can lead to high economic impacts but insignificant social impacts. They further proposed policy implications to improve the benefits of coordination. These policy implications for improvement addressed the issues like consumption effect, investment effect, government purchase effect and external demand effect. The policy implications recommended by the authors were in the context of: (1) supply and demand of urban public transportation infrastructure for economic development, (2) raising service levels and standards of living by provision of infrastructure, (3) environmental value association of public transportation infrastructure and (4) proportionate distribution of benefits of social, environmental and economic impacts of urban public transport infrastructure.

\section{Benefit-cost analysis in the context of public transit systems}

In the particular context of mass rapid transit systems, White, Turner and Mbara (1992) developed upon the financial analysis by the transport studies group of the Polytechnic of central London on minibus development in Britain and applied the benefit-cost analysis for the case. Their findings indicated that although a highfrequency minibus service may not necessarily reduce the passenger waiting times when compared to conventional bus service, the improved convenience may 
shift the demand leading to higher ridership, and therefore more benefits. Pucher and Markstedt (1983) in their article examined the impacts of subsidies and public ownership for mass transit and concluded that although the financial model was instrumental in keeping down fares and enabling system expansion, both of which can be considered beneficial to the transit rider; this type of financial system has also led to wasteful cost escalation and therefore can be viewed as a loss. Their conclusions were based on regression analysis techniques performed on case studies of four large mass transit systems in the United States of America (USA). Johansson et al. (2017) analysed regional public transport planning in Sweden using interview based techniques. Their investigation revealed that benefit-cost analysis was hardly used for the appraisal of the investigated public transport projects which mainly relied upon monitoring of trends. The researchers have given more importance to the relevance of the economic analysis of the public transit as opposed to the methodology of planning public transit and anticipated that the broader role of public transit will increase goal conflicts between authorities. Miller et al. (2016) reviewed the social, economic and environmental impacts of public transportation for meeting sustainability goals of cities and regions and offered recommendations on the sustainable performance of public transit.

\section{Benefit-cost analysis in the context of electric vehicles}

With the advent of electric vehicle technology and much interest shown by urban local bodies for the implementation of clean transport modes, the benefit-cost analysis studies have also found applications in this area. Massiani (2015) critically observed that electric vehicle policies in developed countries lack sufficient attention from economists while addressing social costs and benefits. They identify that the modelling issues and regulatory framework are major responsible factors for the electric vehicle diffusion scenario in Germany. Their study reveals that most of the investigated policies are not beneficial. A similar investigation has been carried out by Ito and Managi (2015) wherein they employ benefit-cost analysis to examine the economic validity of the diffusion of fuel cell vehicles and all-electric vehicles over a time frame. The purchase cost reduction, gasoline price increase, and $\mathrm{CO}_{2}$ abatement costs have been found influential and the economically beneficial time frame is predicted to be until 2060 for electric vehicle and until 2110 for fuel cell vehicle (FCV). Wang et al. (2015) have used benefit-cost assessment for comparing the profitability of electric taxis and gasoline taxis in China. Their assessment considered purchase cost, usage cost, and other operating costs, and explored three scenarios with increasing gasoline price, increasing electricity price and decreasing battery cost. Their findings quantitatively concluded that the electric taxi can be profitable when the gasoline price increases and the battery cost decreases. Sadek (2012) although recognising the many challenges that prevent successful implementation of electric vehicles, has emphasised on the necessity of green vehicles. In an attempt to encourage the deployment of electric vehicles, the researcher has presented a contemporary business case in favour of electric vehicles and ideas to overcome technology and penetration barriers. Successful realisations of such projects, as well as value creation of business, also depend on the business strategies and benefits realisation management as proved by Serra and Kunc (2015). 
Reviewing the available literature, it was observed that efforts to come up with a benefit-cost analysis technique and policy that would aid in bringing down the cost of electric vehicle transport system are widely discussed in research. The major variables identified by various studies included investment costs, demand forecast, purchase cost, subsidies, fuel or electricity costs, battery costs variation, operating costs, values associated with social and human life, natural and built environment characteristics, equity, coordinated development and realisation management strategies. Research related to monetisation of social and environmental values has also been conducted. The main research gap identified based on the reviews is that a strong framework coupling the social and environmental benefits along with economic benefits has not yet been exemplified enough. The case for electric BRTS was not available and therefore, the research means to contribute by a unique case study that also incorporates all three aspects of sustainability.

Thus, the present study aims at the formulation of an SBCA framework for proposed electric bus transit for Ahmedabad and evaluation of the SBCR of the considered case study.

\section{METHODOLOGY}

The methodology for computation of SBCR involves the identification of the benefits or positive effects as well as the costs or negative implications, which may be associated with the development of an electric bus rapid transit system (e-BRTS). For the present case study, SBCR for the e-BRTS has been computed. For the e-BRTS, the proposed route of $185.1 \mathrm{~km}$ has been considered for this research. This $185.1 \mathrm{~km}$ comprises of 8 routes the details of which are presented in Table 1.

Table 1. Route details of e-BRTS of Ahmedabad, India

\begin{tabular}{cclccc}
\hline $\begin{array}{c}\text { Sr. } \\
\text { No. }\end{array}$ & $\begin{array}{c}\text { Route } \\
\text { No. }\end{array}$ & Origin to Destination & $\begin{array}{c}\text { Route Length } \\
(\mathbf{k m})\end{array}$ & $\begin{array}{c}\text { No. of Buses } \\
\text { on the Route }\end{array}$ & $\begin{array}{c}\text { Daily } \\
\text { Vehicle-km }\end{array}$ \\
\hline 1 & 1 & Maninagar to Ghuma Gam & 21.2 & 28 & 3,732 \\
2 & 1 & Ghuma Gam to Maninagar & 19.9 & & 3,631 \\
3 & 2 & Sola Bhagwat to Maninagar & 22.2 & 14 & 3,833 \\
4 & 2 & Maninagar to Sola Bhagwat & 22.9 & & 4,149 \\
5 & 3 & Iscon to Naroda Gam & 22.4 & 22 & 3,833 \\
6 & 3 & Naroda Gam to Isckon & 22.2 & & 3,833 \\
7 & 101 & $\begin{array}{l}\text { RTO Circle to RTO Circle } \\
\text { (Circular route 101) }\end{array}$ & 27.1 & 12 & 4,769 \\
8 & 201 & $\begin{array}{l}\text { RTO Circle to RTO Circle } \\
\text { (Circular route 102) }\end{array}$ & 27.2 & 12 & 4,769 \\
\hline \multicolumn{7}{c}{ Total route length } \\
\hline
\end{tabular}


For the electric bus case, the benefits comprise of: (1) revenue, (2) savings in vehicle operating costs (VOC), (3) environmental benefit, (4) savings in travel time, (5) reduction in accidents and (6) non-consumption of fossil fuel. The associated costs that need to be considered for computation of the SBCA of e-BRTS are primarily:

1. Infrastructure investment costs.

2. Cost of the bus fleet.

3. Maintenance cost.

4. Replacement costs.

5. Cost of system operation and maintenance.

6. Additional electric power generation.

Considering the mentioned benefits, present worth or annual worth analysis was carried out for the net benefits; Present worth or annual worth analysis was also carried out for the net costs. The discount rate for using discounted cash flow techniques is recommended as $10 \%$ in India for public enterprises and 15\% in India for private enterprises that scale predictably. Looking at the nature of the infrastructure to be developed, a public-private partnership would seem inevitable and the discount rate thus adopted is $12 \%$. Further, the rate has been discussed and consulted among project management professionals who have suggested this value. Similarly, the life of the urban bus transport projects is taken as 25 years, since post this, major rehabilitation or change in the system is likely due to the urbanisation impact.

Finally, the benefit-cost analysis was computed by dividing the net benefits by net costs. The benefit-cost analysis has been performed for 25 years life cycle assuming a discount rate of $12 \%$. Data utilised for various heads has been explained in detail in the next section. The data has been gathered in two ways: (1) primary data from interviews with professionals and vendors in the market and (2) secondary data already used previously by some established research in the recent past.

\section{CASE STUDY AND ANALYSIS}

The analysis has been performed for the case data of the bus rapid transit system in the city of Ahmedabad (popularly called Janmarg, incepted in 2009), which currently utilises diesel as the major fuel for the bus locomotion. It is the largest bus rapid transport operation in India transiting around 0.14 million daily passenger traffic using nearly 250 buses on a dedicated route of $97 \mathrm{~km}$ through 158 stations. Recently, the government of India has sanctioned financial assistance for the purchase of 40 electric buses for the city under the faster adoption and manufacturing of (hybrid and) electric vehicles (FAME) Scheme, Department of Heavy Industry, Ministry of Heavy Industries and Public Enterprises (Government of India, 2017). Following this step, the city transport authority intends to appoint and deploy an operator/original equipment manufacturer (OEM) for procurement, operation and maintenance of 40 numbers of air-conditioned midi electric buses on a gross cost contract basis. The selected routes for this first implementation are as illustrated in Table 1. The scope of this research involves 88 electric buses, a corridor length of $185.1 \mathrm{~km}$ and 32,533 daily vehicle-km. 


\section{Benefits}

\section{Revenue generation}

The revenue generated from the electric bus system will comprise of annual revenue directly collected from the users and taxes paid to the government. The revenue of the electric bus system collected from users consists of the ridership revenue and advertisement revenue. The e-BRTS is assumed to be exempted from payment of all types of taxes (income tax, capital gains tax, property tax and customs duty on imports) and therefore the component of tax revenue to the government is nil.

\section{Savings in VOC}

In agreement to the study on SBCA of Delhi metro, it is assumed that the modes of transport such as taxis and three-wheelers are on the road by choice and hence do not get diverted by the implementation of mass rapid transit systems. It is further assumed that by electrification of the BRTS, the diesel based BRTS will cease to exist on the selected routes. Therefore, the primary modes of transport that may be shifted are cars and two-wheelers. The benefits from the reduced number of vehicles on these routes can be identified as follows:

1. VOC reduction due to decongestion.

2. Operating cost reduction of existing diesel BRTS fleet.

The VOC depend upon several factors and have several sub-components and can be computed as the product of the residual traffic, time saved on average lead per vehicle annually and the vehicle operating cost per hour. Savings in vehicle operation cost can happen due to mixed traffic and modal shift. The vehicle operating costs derived by Swaminathan and Kadiyali (1983a) for Indian conditions and used in road user cost study by Swaminathan and Kadiyali (1983b) have been further updated in (RUCS)-2001 by Central Road Research Institute (CRRI). This study provides specifications for both the estimates.

The operating cost of existing diesel BRTS which will be replaced by the e-BRTS is computed as a product of total vehicle-km travelled and operating expenditure per $\mathrm{km}$.

\section{Environmental benefits}

The environmental benefit includes a reduction in tailpipe emissions as well as a reduction in noise pollution. Both the benefits are instrumental in improving the health standards of the community using public transport as well as living in a neighbourhood where public transport operates. Environmental benefits are nonmonetary benefits and difficult to estimate. Most often, these are accounted separately by means of environmental impact assessment studies. However, there have also been efforts to account these along with monetary factors through expressions of SBCA. The environmental benefit for users may be expressed as follows: 
1. Reduction in air pollution

The study by Murty et al. (2006) provides the annualised cost of conversion of technology and annualised incremental production cost of fuel for various vehicle categories. The monetary value of the reduction in pollution due to vehicle reduction is computed as a product of carbon emission reductions (CER) in tons and CER pricing in Indian rupee (INR) per ton CER. The CER is computed based on the relationships provided by the clean development mechanism (CDM) tool of the Intergovernmental Panel on the climate change convention. The particular set of relationships used is derived from the methodology AM0031 of CDM which supports the CER due to modal shift. The CER price is estimated at INR2O per ton $\mathrm{CO}_{2}$ (based on European energy exchange rates in December 2018). The estimates of the monetary value of air pollution reduction thus obtained are tabulated in Table 2.

Table 2. Estimation of Monetary Value of Pollution Reduction through Proposed e-BRTS in Ahmedabad, India

\begin{tabular}{lcccc}
\hline Traffic Mode & $\begin{array}{c}\text { Diverted } \\
\text { Traffic }\end{array}$ & $\begin{array}{c}\text { Annualised Cost } \\
\text { of Conversion of } \\
\text { Technology Per } \\
\text { Vehicle (INR) }\end{array}$ & $\begin{array}{c}\text { Annualised } \\
\text { Incremental } \\
\text { Production Cost of } \\
\text { Fuel Per Vehicle (INR) }\end{array}$ & $\begin{array}{c}\text { Monetary Value of } \\
\text { Reduction in Pollution } \\
\text { Due to Fewer Vehicle } \\
\text { (INR Million) }\end{array}$ \\
\hline Two-wheelers & 24,640 & 4,622 & 816 & 134 \\
Car & 24,640 & 5,312 & 1,876 & 177 \\
Bus & 88 & 17,212 & 14,790 & 2.82 \\
\hline Total & & & 314 million \\
\hline
\end{tabular}

2. Due to the reduction in noise pollution

Report by GGGI and CSTEP (2015) reflects that the diesel buses generate noise at about $70 \mathrm{~dB}$ whereas electric buses are found to generate noise around $60 \mathrm{~dB}$ although noise levels generated are also influenced by a number of factors such as the operating speed, pavement types, airports, other traffic, etc., the reduction in noise from electric buses is assumed to be significant in context of urban India. In the absence of availability of more context-specific data, monetisation factors of the UK have been applied for this computation.

\section{Benefits to users due to savings in travel time}

Since the e-BRTS plies on a dedicated corridor, there would be higher average speed attained. The savings in the travel time of the diverted commuters is based on the trips saved due to the mode shift and time value for work and non-work trips. The value of time for work trips is estimated based on the study by AJL (2016) and the value of time for non-work trips is considered about $30 \%$ of the value of work trips based on guidelines by World Bank. The vehicle-km of diverted traffic has been estimated as a product of number of diverted vehicles, average trip length of each vehicle and the number of trips made by the vehicle. The computation has been illustrated in Table 3. 
Table 3. Estimation of Monetary Value of Total Travel Time Savings for Proposed e-BRTS in Ahmedabad, India

\begin{tabular}{lc}
\hline Component & Estimation \\
\hline $\begin{array}{l}\text { Number of daily passengers travelling for work trips (as explained in } \\
\text { text) }\end{array}$ & 23,280 \\
$\begin{array}{l}\text { Number of daily passengers travelling for non-work trips (as } \\
\text { explained in text) }\end{array}$ & 26,000 \\
Value of time associated with work trips (as explained in text) & INR140 per h \\
Value of time associated with non-work trips (as explained in text) & INR42 per h \\
Average trip length in Ahmedabad & $6.2 \mathrm{~km}$ \\
Average speed of trips in mix traffic & $20.65 \mathrm{kmph}$ \\
Average speed of e-BRTS & $22.5 \mathrm{kmph}$ \\
Passenger time consumed per trip in mix traffic scenario & $0.3 \mathrm{~h}$ \\
(calculated) & \\
Passenger time consumed per trip using e-BRTS (calculated) & $0.275 \mathrm{~h}$ \\
Average number of trips per day (as explained in text) & 2.59 \\
Daily saving in travel time per passenger & $0.064 \mathrm{~h}$ \\
Annual value of travel time saving (work trips) & INR76.06 million \\
Annual value of travel time saving (non-work trip) & INR25.48 million \\
Annual total travel time savings & INR101.55 million \\
\hline
\end{tabular}

\section{Benefits due to the reduction in accidents}

The road accident profile of Ahmedabad reveals 1,837 accidents among which 318 were fatal. A total of 328 people were killed and 1,722 were injured as a result of these accidents. There is sufficient statistical evidence that suggests that BRTS Ahmedabad has facilitated the reduction of road accidents mainly because of the corridor working against wrong side driving habits. The road user cost study in India illustrates the following relationships between the number of vehicles affected and the number of persons killed and injured in road accidents:

$$
\begin{aligned}
& P K=49.43 \mathrm{~V}+750.42 ; R^{2}=0.89 \\
& P I=257.04 \mathrm{~V}+3,181.41 ; R^{2}=0.90 \\
& V D=143.63 \mathrm{~V}+3,345 ; R^{2}=0.84
\end{aligned}
$$

where,

$\checkmark$ : Number of vehicles affected in lakhs (1 lakh $=0.1$ million), PK: Number of persons killed in road accidents in a particular year, PI: Number of persons injured in road accidents in a particular year and VD: Number of vehicles causing damage to property. 
The relationships reflected herein are established in 1983 but are still in use for most such socio-economic analysis as reflected in research by Murty et al. (2006). The number of vehicles corresponds to the diverted vehicles as these represent the reduction in the vehicles likely to be involved in an accident.

The benefits due to the reduction in accidents are calculated by first applying the relationship between diverted vehicles and corresponding accidents reduced, and then by computing the product of reduced accidents with corresponding compensation costs. The computed values are illustrated in Table 4.

Table 4. Compensation Costs Associated with Accidents for Proposed e-BRTS in Ahmedabad, India

\begin{tabular}{lcccc}
\hline Cost Component & $\begin{array}{c}\text { Diverted } \\
\text { Traffic (V) }\end{array}$ & $\begin{array}{c}\text { Reduction in Injuries, } \\
\text { Fatalities and Vehicle } \\
\text { Damage (PK/PI/VD) }\end{array}$ & $\begin{array}{c}\text { Value } \\
\text { (INR) }\end{array}$ & $\begin{array}{c}\text { Annual } \\
\text { Compensation } \\
\text { (INR Million) }\end{array}$ \\
\hline $\begin{array}{l}\text { Cost of fatal accident } \\
\begin{array}{l}\text { Cost of non-fatal } \\
\text { accidents/injuries }\end{array}\end{array}$ & 49,280 & 24.36 & 437,342 & 10.65 \\
$\begin{array}{l}\text { Cost of property damage } \\
\text { due to two-wheelers }\end{array}$ & 49,280 & 126.7 & 64,256 & 8.14 \\
$\begin{array}{l}\text { Cost of property damage } \\
\text { due to cars }\end{array}$ & 24,640 & 35.42 & 2,286 & 0.08 \\
\begin{tabular}{l} 
Total cost of accidents \\
\hline
\end{tabular} & & 35.42 & 9,763 & 0.35 \\
\hline
\end{tabular}

\section{Benefit due to savings accrued due to non-consumption of fossil fuel}

The benefits due to savings of non-consumption of fossil fuels constitute those that are contributed by the diverted traffic (two-wheelers and cars) as well as the ceasing of the diesel BRTS. These have been estimated as a product of the total vehicle-km travelled due to various modes, their respective mileages and unit cost of fuel. The fuel for two-wheelers and cars is assumed to be petrol (with a unit cost of INR74.72 per litre) and the fuel for buses is assumed to be diesel (with a unit cost of INR72.27 per litre). The fuel costs are June 2018 prices and total monetary savings due to non-consumption of fossil fuels are illustrated in Table 5.

Table 5. Savings Due to Non-Consumption of Fossil Fuels for Proposed e-BRTS in Ahmedabad, India

\begin{tabular}{lccccc}
\hline Traffic Mode & $\begin{array}{c}\text { Daily } \\
\text { Vehicle- } \\
\text { km }\end{array}$ & $\begin{array}{c}\text { Fuel Consumption } \\
\text { or Mileage } \\
\text { (km Per Litre) }\end{array}$ & $\begin{array}{c}\text { Total Fuel } \\
\text { Consumed } \\
\text { in Litres }\end{array}$ & $\begin{array}{c}\text { Fuel Price } \\
\text { (INR Per } \\
\text { Litre) }\end{array}$ & $\begin{array}{c}\text { Total Annual Value } \\
\text { of Fuel Savings in } \\
\text { Million INR }\end{array}$ \\
\hline Four-wheelers & $3,95,669$ & 18.2 & 21,740 & 74.72 & 593 \\
Two-wheelers & $3,95,669$ & 50 & 7,913 & 74.72 & 216 \\
Buses & 32,548 & 2.2 & 14,795 & 72.27 & 390 \\
\hline Total & & & & 1,199 \\
\hline
\end{tabular}




\section{Costs}

\section{Investment costs}

The investment costs included herein are the capital cost of BRTS corridor development calculated in proportion to the corridor length and capital cost of charging infrastructure development. The BRTS Infrastructure development costs include capital costs attached to the development of the BRTS corridor, BRTS bus shelters, depot, sliding doors, terminal and hardware/software for the intelligent transport system.

The charging stations required for the electric buses are assumed to be conductive charging stations which are currently popular in other countries with electric bus mobility. The standards for charging infrastructure are still evolving in India but market cost based on charging specifications reported in some literature maybe as much as INR3.5 million each. Based on charging time and bus scheduling requirements, one charger per bus is assumed.

\section{The capital cost of bus procurement}

The capital expenditure incurred has been accounted for based on current market price and taking into effect sanctioned subsidy by the government of India for the city e-BRTS.

\section{Annual infrastructure maintenance cost (civil)}

The annual BRTS corridor maintenance cost for the civil components has been approximated in proportion to corridor length proposed for e-BRTS.

\section{Cost of replacement of intelligent transport management system (ITMS) infrastructure}

The ITMS equipment replacement costs (hardware, software and fibre optic electronics) are also approximated in proportion to corridor length proposed for e-BRTS and expected to recur every seven years.

\section{Cost of replacement of buses}

The cost of bus replacement is considered to be the same as the capital cost of buses and is expected to occur at the end of 15 years in the analysis.

\section{Cost of battery replacement}

Due to the range and power requirements of buses, the electric bus batteries are of high storage type and have been cited to contribute as a major cost component of the system. There are many battery technologies in the market depending upon variations in anode, cathode and electrolyte combinations. Lead acid batteries, nickel-based aqueous batteries, and lithium-ion batteries are common technologies that exist, lithium ion being the most popular one and are assumed for cost calculations. 


\section{Cost of system operation and maintenance}

The cost of e-BRTS operation and maintenance is envisaged to be comprised of the cost of electricity, cost of maintenance, and cost of skilled and unskilled manpower. The city has adopted a gross cost contract model for procurement, operation, and maintenance of e-BRTS Ahmedabad wherein the bus would be operated and maintained by the supplier (TATA Motors Ltd., India) at INR59 per km.

\section{Cost of additional electric power generation}

Transition to electric mobility for buses means additional power or electricity required from the grid which will be transferred to the vehicle through charging stations. It is anticipated that the energy requirement of a typical electric bus is around $325 \mathrm{kWh}$ and depending on the size of the fleet the total power requirement has been assessed. Although presently, the electricity grid is supplied by a mix of thermal and renewable energy, the cost of future power is based on captive solar power plant generation.

\section{Power plant installation}

In order to account for the solar power plant size and cost required for the e-BRTS

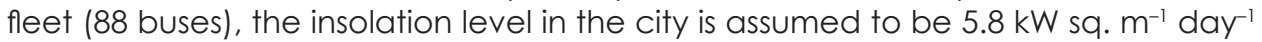
and the cost of a $100 \mathrm{~kW}$ solar captive system is estimated at INR7.5 million. The energy requirement and system size are calculated as follows:

$$
\begin{aligned}
& \text { Energy requirement }=88 \times 325=28,600 \mathrm{kWh} \\
& \text { System size }=28,600 \times 1.3 / 5.8=6,410 \mathrm{kWp}
\end{aligned}
$$

\section{Power distribution and transmission}

About $95 \%$ of the cost of transmission and distribution of electric power constitutes the capital cost of transmission and distribution infrastructure. The capital cost for transmission and distribution infrastructure for the additional power (Ctd) is estimated as USD0.019 billion $\mathrm{GW}^{-1}$ and capital cost of distribution grid as USD0.006 billion $\mathrm{GW}^{-1}$, based on which a total expenditure of INR 11 million can be estimated for transmission and distribution infrastructure. The operating expenses for the same are found to be highly insignificant and therefore not accounted for. 
Table 6. Summary of Benefits and Costs for Proposed e-BRTS in Ahmedabad, India

\begin{tabular}{|c|c|c|c|c|}
\hline & Benefits & Account Basis & INR Million & Type \\
\hline \multirow[t]{3}{*}{1} & Total revenue & & & \\
\hline & Ridership & $\begin{array}{l}49,280 \text { passengers daily in proportion to } \\
\text { the existing BRTS statistics and average } \\
\text { fare of INR } 10 \text { per passenger. }\end{array}$ & 179.87 & Annual \\
\hline & Advertisement & $\begin{array}{l}\text { Advertisement tariff is INR87, } 000 \text { per bus } \\
\text { per year. }\end{array}$ & 7.66 & Annual \\
\hline \multirow[t]{3}{*}{2} & $\begin{array}{l}\text { Savings in vehicle } \\
\text { operation costs }\end{array}$ & & & \\
\hline & $\begin{array}{l}\text { Diverted traffic VOC } \\
\text { saving }\end{array}$ & $\begin{array}{l}49,280 \text { passengers daily, } 50: 50 \% \text { mode } \\
\text { split of cars and two-wheelers with } \\
\text { single occupancy, no increase in figure } \\
\text { due to capacity constraints of BRTS, } \\
\text { proportionate VOC saving estimated } \\
\text { according to INR27 per km operating } \\
\text { cost of buses, INR } 15 \text { per km operating } \\
\text { cost of cars and two-wheelers, and fuel } \\
\text { consumption of } 3,18 \text { and } 50 \mathrm{~km} \text { per } \\
\text { litre for two-wheelers, cars and buses, } \\
\text { respectively. }\end{array}$ & 269.6 & Annual \\
\hline & $\begin{array}{l}\text { Non operation of } \\
\text { diesel buses }\end{array}$ & & 320.76 & Annual \\
\hline \multirow[t]{3}{*}{3} & Environmental benefits & & & \\
\hline & $\begin{array}{l}\text { Reduction in } \\
\text { air pollution }\end{array}$ & & 314 & Annual \\
\hline & $\begin{array}{l}\text { Reduction in } \\
\text { noise pollution }\end{array}$ & $\begin{array}{l}£ 20.77 \text { per person according to } \\
\text { Department for Environment Food and } \\
\text { Rural Affairs (2014), beneficiaries are } \\
49,280 \text { daily riders and } 0.96 \text { million people } \\
\text { residing in immediate vicinity of } 0.5 \mathrm{~km} \\
\text { along the corridor of } 185.1 \mathrm{~km} \text { as per } \\
\text { demographics by United Nations (2016) } \\
\text { (Exchange rate assumed: } £ 1=\text { INR89.87). }\end{array}$ & $1,802.6$ & Annual \\
\hline 4 & $\begin{array}{l}\text { Savings in travel } \\
\text { time }\end{array}$ & Refer Table 5. & 101.55 & Annual \\
\hline \multirow[t]{4}{*}{5} & Reduction in accidents & & & \\
\hline & $\begin{array}{l}\text { Fatal accidents } \\
\text { reduction }\end{array}$ & & 10.65 & Annual \\
\hline & $\begin{array}{l}\text { Non-fatal accidents } \\
\text { reduction }\end{array}$ & & 8.14 & Annual \\
\hline & $\begin{array}{l}\text { Vehicle damage } \\
\text { reduction }\end{array}$ & & 0.43 & Annual \\
\hline
\end{tabular}


Table 6. (continued)

\begin{tabular}{|c|c|c|c|c|}
\hline & Benefits & Account Basis & INR Million & Type \\
\hline \multirow[t]{3}{*}{6} & $\begin{array}{l}\text { Savings in fossil fuel } \\
\text { consumption }\end{array}$ & $\begin{array}{l}\text { INR74.72 per litre for petrol, INR72.27 per } \\
\text { litre for diesel (as shown in Table } 7 \text { ). }\end{array}$ & 1,199 & Annual \\
\hline & Total & & $4,214.26$ & Annual \\
\hline & Cost & & & \\
\hline \multirow[t]{3}{*}{1} & $\begin{array}{l}\text { Infrastructure } \\
\text { investment costs }\end{array}$ & & & \\
\hline & $\begin{array}{l}\text { Capital cost of } \\
\text { corridor development }\end{array}$ & & 11,241 & Capital \\
\hline & $\begin{array}{l}\text { Capital cost of } \\
\text { charging } \\
\text { infrastructure } \\
\text { development }\end{array}$ & $\begin{array}{l}\text { INR3.5 million per charger, one charger } \\
\text { per bus. }\end{array}$ & 308 & Capital \\
\hline 2 & $\begin{array}{l}\text { Capital cost of bus } \\
\text { procurement }\end{array}$ & $\begin{array}{l}\text { INR25 million per bus market rate, } 40 \\
\text { buses with subsidy as per and subsidy } \\
\text { provision as per and } 48 \text { buses at } \\
\text { maximum retail price. }\end{array}$ & 2,000 & Capital \\
\hline 3 & $\begin{array}{l}\text { Infrastructure } \\
\text { maintenance cost }\end{array}$ & & 139 & Annual \\
\hline 4 & $\begin{array}{l}\text { Cost of replacement } \\
\text { of ITMS infrastructure }\end{array}$ & & 618 & $\begin{array}{l}\text { Every } 7 \\
\text { years }\end{array}$ \\
\hline 5 & $\begin{array}{l}\text { Cost of replacement } \\
\text { of buses }\end{array}$ & Same as cost item (2). & 2,000 & $\begin{array}{l}\text { After } 15 \\
\text { years }\end{array}$ \\
\hline 6 & $\begin{array}{l}\text { Cost of battery } \\
\text { replacement }\end{array}$ & $\begin{array}{l}\text { Lithium ion batteries with typical cost } \\
\text { range from INR30,000 to INR65,000 per } \\
\text { kWh, life of } 5 \text { years, } 88 \text { numbers of } 325 \\
\text { kWh electric buses, } 1 \text { battery per bus. }\end{array}$ & 1,358 & $\begin{array}{l}\text { Every } 5 \\
\text { years }\end{array}$ \\
\hline 7 & $\begin{array}{l}\text { Cost of system } \\
\text { operation and } \\
\text { maintenance }\end{array}$ & $\begin{array}{l}\text { According to gross cost contract model } \\
\text { and INR59 per km, and } 32,548 \text { daily } \\
\text { vehicle-km travelled by the e-BRTS. }\end{array}$ & 701 & Annual \\
\hline 8 & $\begin{array}{l}\text { Cost of additional } \\
\text { electric power } \\
\text { generation }\end{array}$ & $\begin{array}{l}88 \text { buses, } 325 \mathrm{kWh}, 5.8 \mathrm{~kW} \text { sq. } \mathrm{m}^{-1} \text { day }^{-1} \\
\text { insolation, INR7.5 million per } 100 \mathrm{kWp} \text { for } \\
\text { solar power plant installation, system size } \\
6,410 \mathrm{kWp} \text { as computed, USD0.019 billion } \\
\mathrm{GW}^{-1} \text { and capital cost of distribution grid } \\
\text { as USD0.006 billion } \mathrm{GW}^{-1} \text {. }\end{array}$ & 491.75 & Capital \\
\hline
\end{tabular}


The cash flow diagram benefits and costs of the proposed e-BRTS are presented in Figures 1 and 2.

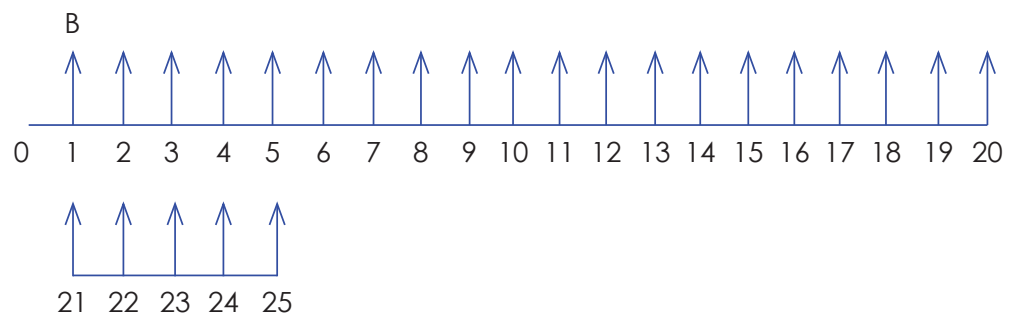

Figure 1. Cash Flow Diagram for Benefits of Proposed e-BRTS for Ahmedabad, India

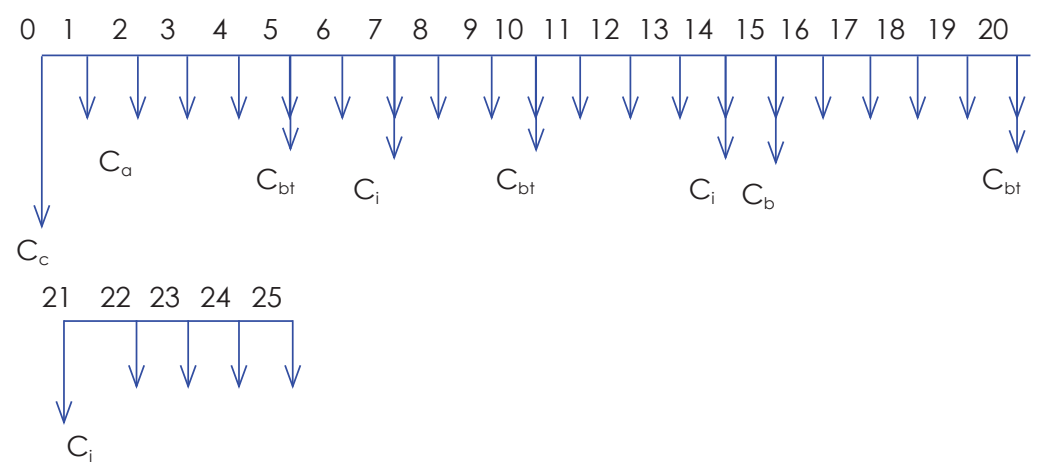

Figure 2. Cash Flow Diagram for Costs of Proposed e-BRTS for Ahmedabad, India

Considering uniform series present worth, the present value of the annuity (P/A) can be obtained by the following equation:

$$
\frac{P}{A}=\frac{(1+i)^{n}-1}{i^{*}(1+i)^{n}}
$$

The single payment present worth can be obtained by the following equation:

$$
\frac{P}{F}=\frac{1}{(1+i)^{n}}
$$

For the analysis case, the discount rate is $12 \%$ and the period of evaluation, $n$ is 25 years.

The total annual benefits account to INR4214.26 million, which correspond to present worth of INR33,053 million (USD479.03 million). 
The total capital cost account to INR12,040.75 million and annual cost accounts to INR840 million. The one-time battery replacement cost at 5, 10 and 20 years is INR 1,358 million and a one-time cost of bus replacement at 15 years is INR2,000 million. The one-time cost of ITMS infrastructure replacement at 7, 14 and 21 years is INR618 million. The total present worth of these costs is $22,806.21$ million.

Table 7. Computation of Present Worth of All Costs and Benefits for Proposed e-BRTS in Ahmedabad, India

\begin{tabular}{lccc}
\hline & $\begin{array}{c}\text { Value in INR } \\
\text { Million }\end{array}$ & PW Factor & $\begin{array}{c}\text { Present Worth in } \\
\text { INR Million }\end{array}$ \\
\hline Total benefits & $4,214.26$ & 7.8431 & 33,053 \\
Costs & $12,040.75$ & 1 & $12,040.75$ \\
Capital cost & 840 & 7.8431 & $6,588.24$ \\
Annual cost & 1,358 & $(0.567,0.3220,0.1037)$ & $1,348.63$ \\
Battery replacement cost & 2,000 & at 5, 10 and 20 years & 365.39 \\
Bus replacement cost & 618 & (0.4523, 0.2046, 0.0926) & 463.2 \\
ITMS infrastructure & & at 7, 14 and 21 years & \\
replacement cost & & & $20,806.21$ \\
\hline Total cost & &
\end{tabular}

The SBCR as represented by the ratio of the present worth of net benefits to the present worth of net costs comes out to be 1.45. Similarly, the SBCR of proposed e-BRTS for a $12 \%$ discount rate and 25 years life cycle is 1.45 . Similarly, the SBCR at $8 \%, 10 \%$, and $18 \%$ discount rates come out to be $1.72,1.58$ and 1.15 , respectively.

\section{FINDINGS AND RESULTS}

The SBCA study carried out for a life cycle of 25 years for the e-BRTS network under consideration in Ahmedabad revealed a benefit to cost ratio greater than unity indicating that it may be a positive investment for the city if the various socioeconomic factors are also evaluated and considered. The internal rate of return for the project is estimated to be greater than $18 \%$. The study addresses and evaluates various costs and benefits for the case of e-BRTS for Ahmedabad with special efforts to account for the benefits due to the reduction in noise pollution and the costs for power generation which have been neglected by most other studies in the similar domain.

The distribution of the present worth of various benefits and costs has been shown in Figures 3 and 4, respectively. Major environmental benefits (50\%) are anticipated for the case, followed by benefits due to the reduction in fossil fuel consumption (29\%). It is further observed that a huge cost is accrued for the development of such infrastructure (51\%). Transit system operation and maintenance cost $(24 \%)$ is another major component involved. 


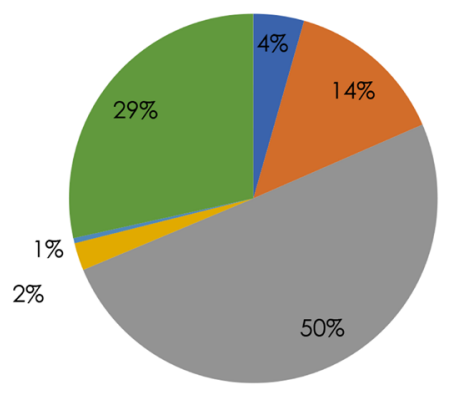

- Revenue benefits

- Savings in vehicle operation costs

- Environmental benefits

- Savings in travel time

- Savings in accident costs

- Saving in fossil fuel consumption

Figure 3. Distribution of Various Benefits for SBCA for Proposed e-BRTS in Ahmedabad, India

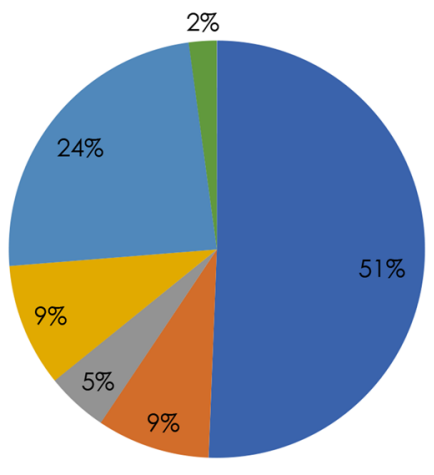

- Infrastructure Investment costs

Bus procurement cost

Infrastructure maintainence cost

neplacement costs of ITMS infrastructure, buses and batteries

- Transit system operation and maintainance cost

- Cost of additional power generation

Figure 4. Distribution of Various Costs for SBCA for Proposed e-BRTS in Ahmedabad, India

Some benefits are associated with the inherent existence of the BRTS in general such as revenue generation, diverted traffic VOC, travel time savings and accident reduction and will continue remaining as benefits for the e-BRTS as well. But it is the highly significant amount of additional benefits such as pollution reduction, savings in fossil fuel consumption and VOC savings of diesel buses, that needs to be captured.

Similarly, whereas the costs associated with the implementation of the BRTS in general such as corridor development, infrastructure maintenance cost, ITMS equipment replacement costs and system operation and maintenance costs are significant and unavoidable, some additional costs of charging infrastructure development, bus procurement and replacement, battery replacement and electric power generation are also expected for the e-BRTS to be in place. The most significant future cost component envisaged is the cost of bus, charging stations and battery replacement, which constitute $15 \%$ to $20 \%$ of the total life-cycle cost.

Figures 5 and 6 provide indicative distribution of benefits and costs that are involved anyhow with the existing BRTS and those associated with the changeover to e-BRTS. Therefore, if the benefits and costs were to be evaluated in terms of existing and future expectations, the additional benefits due to e-BRTS which 
constitute $86 \%$ of the benefits (INR28,520 million) far outweigh the costs due to e-BRTS which constitute only $20 \%$ of the additional costs (INR4,515 million). This is a significant finding as it supports the fact that the e-BRTS can lead to value addition of what has already been invested in existing BRTS.

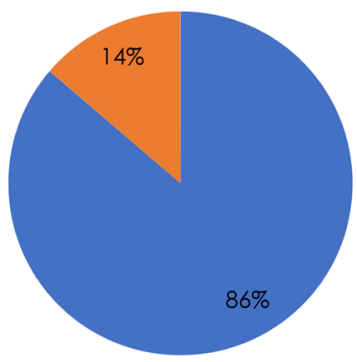

- Additional benefits due to e-BRTS

m Benefits attributed to BRTS in general

Figure 5. Scenario of Existing BRTS Benefits as Compared to Additional Benefits Due to Proposed e-BRTS in Ahmedabad, India

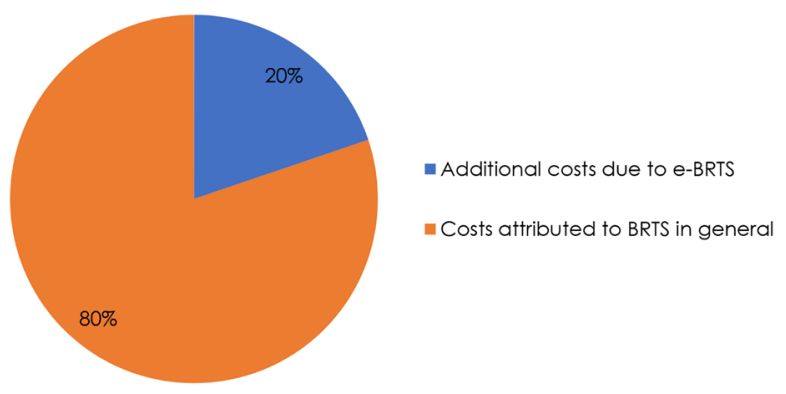

Figure 6. Scenario of Existing BRTS Costs as Compared to Additional Costs Due to Proposed e-BRTS in Ahmedabad, India

\section{CONCLUSION}

This research presents a comprehensive SBCA for evaluating the implementation case for the electric bus transport system. The analysis has been applied for the case of Ahmedabad, India where the electric bus system is being proposed along eight routes. The fundamental rigor behind electrifying bus transport is because of its sustainability values. This research addresses the justification of the concept by actual quantitative analysis and thus contributes by illustrating that the SBCA may be used as a tool for supporting both sustainability concerns and appraisals of such otherwise financially less viable transport projects.

After analysing the case considered for this study, it can be concluded that the electric BRTS implementation for the selected network in the city is favourable as the present worth of benefits exceeds those of the costs. The life cycle benefits accrued are to the tune of INR 1.02 million per daily vehicle-km whereas the life cycle costs are to the tune of INR0.64 million per daily vehicle-km, thus resulting in 
a net advantage of about INR0.38 million per vehicle-km. The benefit-cost ratio for a discount rate of $12 \%$ and the life cycle of 25 years is found to be 1.45 and the internal rate of return is estimated at greater than $18 \%$. The benefit-cost ratio at $8 \%$, $10 \%$ and $18 \%$ discount rates are estimated to be $1.72,1.58$ and 1.15 , respectively.

The major beneficiaries are the road users and as much as $50 \%$ of the benefits (amounting to INR16,600 million [USD255 million] for the studied case) can be attributed to life cycle environmental benefits. The major cost $(51 \%)$ involved in the implementation of an e-BRTS project is for infrastructure development amounting to INR 1 1,549 million (USD178 million) for the studied case, its major subcomponent being corridor development.

A significant finding of the detailed existing and future benefit-cost components for the context-specific case studied revealed that additional benefits are foreseen due to e-BRTS (86\% or INR28,250 million [USD 435 million]) far outweigh the additional costs (20\% or INR4,514 million [USD 69 million]) incurred for its successful implementation. This is viewed as a value addition to the efforts and investment already put in by the city for various socio-economic causes.

This type of study is useful to support the possibility of implementation of sustainable modes of transport such as the e-BRTS by using traditional benefit-cost ratio technique but with added vision and values of social and environmental factors. As illustrated by the case studied herein, the financial factor alone cannot justify the feasibility of the public transport infrastructure, but its multiple other types of benefits, when considered through the tool of SBCA, can be a change maker for the situation. The financial benefit is a very small percentage of the total benefits (including social and environmental also) and therefore the benefit-cost ratio being computed by existing analysis framework is much improved by this approach of the SBCR, especially from the perspective of the transportation system as a whole.

Whereas high financial returns may not be expected from the e-BRTS, the project at large can be called sustainable looking to the many benefits to the road users and its fruitful socio-economic perspectives.

The future scope of research may address efforts to develop a stronger and self-sustaining financial model that may enable electric bus mobility in Indian cities.

\section{SCOPE FOR FUTURE RESEARCH}

The future scope of this research work lies in strategic phase-wise planning for maximum early benefit and optimisation of resources such as charging stations. Further, a suitable public-private partnership model that can aid and enable faster development by supporting a high capex on the finance side and operation maintenance on the responsibility side may be developed.

\section{ACKNOWLEDGEMENTS}

The authors would like to thank Pandit Deendayal Petroleum University (PDPU) and all concerned transportation authorities for providing the necessary facilities to carry out this investigation. 


\section{REFERENCES}

AJL (Ahmedabad Janmarg Limited) (2018). Request for proposal (RFP) for selection of bus operator for procurement, operation and maintenance of MIDI AC fully built pure electric buses on gross cost contract basis. Available at: http:// www.ahmedabadbrts.org/web/documents/Vol-III_Bus\%20specifications_ RFS\%202.pdf [Accessed on 3 July 2018].

(2016). Socio Economic Costs Benefit Analysis of Ahmedabad BRTS. Ahmedabad: AJL. Available at: http://shodhganga.inflibnet.ac.in/ bitstream/10603/189686/14/15_chapter6.pdf [Accessed on 3 July 2018].

Anas, R., Tamin, O. and Wibowo, S.S. (2016). Applying input-output model to estimate broader economic impact of transportation infrastructure investment. Journal of the Institution of Engineers (India): Series A, 97: 323-331. https://doi.org/10.1007/s40030-016-0170-2.

Asplund, D. and Eliasson J. (2016). Does uncertainty make cost-benefit analyses pointless? Transportation Research Part A: Policy and Practice, 92: 195-205. https://doi.org/10.1016/j.tra.2016.08.002.

Barrell, D.W.F. and Hills, P.J. (1972). The application of cost-benefit analysis to transport investment projects in Britain. Transportation, 1: 29-54. https://doi. org/10.1007/BF00167507.

DeCorla-Souza, P., Everett, J., Gardner, B. and Culp, M. (1997). Total cost analysis: An alternative to benefit-cost analysis in evaluating transportation alternatives. Transportation, 24: 107-123. https://doi.org/10.1023/A:1004949400677.

Department for Environment Food and Rural Affairs (2014). Environmental Noise: Valuing Impacts on: Sleep Disturbance, Annoyance, Hypertension, Productivity and Quiet. London: Department for Environment Food and Rural Affairs. Available at: https://assets.publishing.service.gov.uk/government/ uploads/system/uploads/attachment_data/file/380852/environmentalnoise-valuing-imapcts-PB14227.pdf [Accessed on 3 July 2018].

EMA (Electric Mobility Alliance) (2017). Deployment of electric buses in India. Available at: http://www.astu.org/wp-content/uploads/2017/05/Deployment -of-electric-buses-in-India.pdf [Accessed on 3 July 2018].

Florio, M. and Sirtori E. (2016). Social benefits and costs of large scale research infrastructures. Technological Forecasting and Social Change, 112: 65-78. https://doi.org/10.1016/j.techfore.2015.11.024.

GGGI (Global Green Growth Institute) and CSTEP (Center for Study of Science, Technology and Policy) (2015). Electric Buses in India: Technology, Policy and Benefits. Seoul: GGGI. Available at: http://www.cstep.in/uploads/ default/files/publications/stuff/CSTEP_Electric_Buses_in_India_Report_2016. pdf [Accessed on 3 July 2018].

Government of India (2017). Scheme for Faster Adoption and Manufacturing of (Hybrid \&) Electric Vehicles in India. New Delhi: Department of Heavy Industry, Ministry of Heavy Industries and Public Enterprises. Available at: https://dhi.nic.in/UserView/index?mid=2418 [Accessed on 3 July 2018].

Hickman, R. and Dean, M. (2017). Incomplete cost: Incomplete benefit analysis in transport appraisal. Transport Reviews, 38(6): 689-709. https://doi.org/10 $.1080 / 01441647.2017 .1407377$.

Ito, Y. and Managi, S. (2015). The potential of alternative fuel vehicles: A costbenefit analysis. Research in Transportation Economics, 50: 39-50. https://doi.org/10.1016/j.retrec.2015.06.005Get. 
Johansson, E., Hiselius, L., Koglin, T. and Wretstrand, A. (2017). Evaluation of public transport: Regional policies and planning practices in Sweden. Urban Planning and Transport Research, 5(1): 59-77. https://doi.org/10.1080/ 21650020.2017 .1395291$.

Martens, K. and Floridea, D. (2017). Travel time savings, accessibility gains and equity effects in cost-benefit analysis. Transport Reviews, 37(2): 152-169. https://doi.org/10.1080/01441647.2016.1276642.

Massiani, J. (2015). Cost-benefit analysis of policies for the development of electric vehicles in Germany: Methods and results. Transport Policy, 38: 19-26. https://doi.org/10.1016/j.tranpol.2014.10.005.

Miller, P., De Barros, A.G., Kattan, L. and Wirasinghe, S.C. (2016). Public transportation and sustainability: A review. KSCE Journal of Civil Engineering, 20: 1076-1083. https://doi.org/10.1007/s12205-016-0705-0.

Mouter, N., Annema, J.A. and Van Wee, B. (2015). Managing the insolvable limitations of cost-benefit analysis: Results of an interview based study. Transportation, 42: 277-302. https://doi.org/10.1007/s 1111 16-014-9539-0.

Murty, M., Dhavala, K., Ghosh, M. and Singh, R. (2006). Social Cost-Benefit Analysis of Delhi Metro. Delhi: Institute of Economic Growth. Available at: http://www. iegindia.org/upload/publication/Workpap/wp273.pdf [Accessed on 3 July 2018].

Pucher, J. and Markstedt, A. (1983). Consequences of public ownership and subsidies for mass transit: Evidence from case studies and regression analysis. Transportation, 11:323-345. https://doi.org/10.1007/BF00150722.

Sadek, N. (2012). Urban electric vehicles: A contemporary business case. European Transport Research Review, 4: 27-37. https://doi.org/10.1007/ s12544-011-0061-6.

Serra, C. and Kunc, M. (2015). Benefits realization management and its influence on project success and on the execution of business strategies. International Journal of Project Management, 33(1): 53-66. https://doi.org/10.1016/ j.ijproman.2014.03.011.

SIAM (Society of Indian Automobile Manufacturers) (2016). Automotive Mission Plan 2016-2026: A Curtain Raiser. New Delhi: SIAM. Available at: http:// www.siamindia.com/uploads/filemanager/47automotivemissionplan.pdf [Accessed on 3 July 2018].

Sun, Y. and Cui, Y. (2018a). Analysing urban infrastructure economic benefit using an integrated approach. Cities, 79: 124-133. https://doi.org/10.1016/j.cities .2018.03.001.

(2018b). Evaluating the coordinated development of economic, social and environmental benefits of urban public transportation infrastructure: Case study of four Chinese autonomous municipalities. Transport Policy, 66: 116-126. https://doi.org/10.1016/j.tranpol.2018.02.006.

Swaminathan, C. and Kadiyali, L. (1983a). Road user cost study in India. Available at: https://trid.trb.org/view/204352 [Accessed on 3 July 2018].

(1983b). Vehicle operating costs under indian road and traffic conditions. Available at: https://trid.trb.org/view/194696 [Accessed on 3 July 2018].

TERI (The Energy and Resources Institute) and YES Bank (2018). Electric mobility paradigm shift: Capturing the opportunities. Available at: https://www. investindia.gov.in/sites/default/files/2018-04/Electric\%20Mobility\%20 Paradigm\%20Shift.pdf [Accessed on 3 July 2018]. 
United Nations (2016). United Nations population estimates and projections of major urban agglomerations. Available at: http://worldpopulationreview.com/ world-cities/ahmedabad-population/ [Accessed on 3 July 2018].

Viton, P.A. (1993). How big should transit be? Evidence on the benefits of reorganization from the San Francisco Bay area. Transportation, 20: 35-57. https://doi.org/10.1007/BF01099975.

Wang, N., Liu, Y., Fu, G. and Li, Y. (2015). Cost-benefit assessment and implications for service pricing of electric taxies in China. Energy for Sustainable Development, 27: 137-146. https://doi.org/10.1016/j.esd.2015.05.008.

White, P.R., Turner, R.P. and Mbara, T.C. (1992). Cost benefit analysis of urban minibus operations. Transportation, 19: 59-74. https://doi.org/10.1007/BF01130774. 